\section{Ethical Lingua}

Journal of Language Teaching and Literature

ISSN 2355-3448 (Print)

ISSN 2540-9190 (Online)

Volume 6, Number 1, August 2019

pp. $30-39$

\title{
Omission: Common Simple Present Tense Errors in Students' Writing of Descriptive Text
}

\author{
Masruddin \\ anthosmithstain@yahoo.com \\ Institut Agama Islam Negeri (IAIN) Palopo, Indonesia \\ Received : 04 November 2018; Accepted: 14 February 2019 \\ URL : $\quad$ https://journal2.uncp.ac.id/index.php/ethicallingua/article/view/1114 \\ DOI : https://doi.org/10.30605/ethicallingua.v6i1.1114
}

\begin{abstract}
This research is aimed to determine and to describe the errors in using simple present tenses in writing descriptive texts made by students, especially in the class $D$ of sixth semester of English Education Department at IAIN Palopo. The data were obtained by conducting a test and using a checklist. Then, the writing products were analyzed using Surface Strategy Taxonomy by Dulay (1982). The result of this research was presented descriptively. From the result, the omission errors were found as the highest of occurrence, which was about $47,05 \%$ which revealed that in the class $D$ of sixth semester in English Education Department at IAIN Palopo, still made errors in using simple present tense in writing descriptive text. The errors that are mostly made by students were errors of omission. It is in line with Dulay (1982) which stated that errors of omission are found in greater abundance during the early stages of second language acquisition.
\end{abstract}

Keywords: descriptive text; simple present tense; writing 


\section{Introduction}

Language is particularly variety or level of speech or writing and people use language for special purposes. People use both spoken and written language to convey their ideas or feelings in various purposes and reasons. Without using any language, people cannot establish social relationship and interact with the others. In Indonesia, English has become one of subjects in formal education. It is taught since the students are in Elementary School. The learners are demanded to master four skills in English. Those are listening, speaking, reading, and writing. English has been taught in all levels of education, from the basic level to advanced level, from primary to secondary school, either for intra-curricular or extracurricular subject. In addition, teaching English is important because if it is successful, the students will be mastered English language. In Indonesia, English is established as a foreign language. The goal of teaching learning English is to make the students mastering English as an international language. They need language to communicate and interact with the others. They use either spoken or written language to communicate. However, many students still face difficulties and usual make errors in learning English as a foreign language because of the great differences between English and Indonesian language. In addition, learning about the second language is not same as learning about the first language (mother tongue). Sometimes, the learner of the second language will make error in producing spoken and written.

Errors are the features of the learners' utterances, which are different from those any native speakers, and the learners do not recognize their errors so that they cannot correct their errors by themselves. When the errors recognized, it call error analysis. Error analysis is the study and analysis of the errors made by the second and foreign language learners. 3 besides the errors can be observed and analyzed, error also can divided into some parts. According to Richards, errors can be can be classified to vocabulary (lexical error), pronunciation (phonological error), grammar (syntactic error), misunderstanding of speaker's intention or meaning (interpretive error), production of intention or meaning (interpretive error), production of the wrong communicative effect e.g. through the faulty use of speech act or one the rule of speaking (pragmatic error).

According to Byrne (1980:24), writing is a primary means of recording speech, even though it must be acknowledged as a secondary medium of communication. It can be concluded that writing is very important as one media of communication that can help people to have a good socialization, express people idea, feeling, and opinion so that the researcher can have a good interaction with people society. Writing is considered the most difficult skill in language teaching and learning process. 
Masruddin:

Omission: Common Simple Present Tense Errors in Students' Writing of Descriptive Text

The students are expected to be able to communicate in English using correct structure. Structure or grammar is one of the basic components of language, which must be learnt by students. It is very useful and important as Raja T. Nasr (1988:52) writes that grammar is a part of any language. Just as there is no language without sounds (at least no live or oral language) so, there is no language without grammar. Having knowledge of grammar will help people to comprehend what other people say or write. On the other hand, it is difficult for Indonesian students to use correct structure in English. This is mostly because the students are influenced by their mother tongue on the acquisition of the new structures.

There are many structures in language. English has some tenses. One of them is simple present that used in descriptive text. The simple present tense is the tense for description, definition, and statements of general truth. Aitken (1992:18) explains, the simple present tense is helpful to express actions which are always, repeatedly, or generally true, or actions occur at the moment of speaking (with no reference to past or future). The present tense of a verb is formed with the simple form of a verb for the first person, and third person plural subject except for third person singular subject; and the verb ends in -s, or -es, (Soemarto and Suharjito, 1994:27). In terms of forms, the simple present can be divided into positive, negative, interrogative, and negative interrogative. The frequently used adverbs or adverbial phrases in the simple present tense include always, often, usually, every day, sometime, never, occasionally, seldom, and twice a week, etc. In addition, simple present tense is used to tell an ability to express an idea, opinion, feeling, or experience that somebody has heard in written form. It can begin from a simple piece of writing to a more advanced level. Descriptive text is when you are describing the way something looks like. More clearly, descriptive writing as present an object, feeling, a place or a person in a way that creates a viscid impression in the reader's mind.

There are many rules in grammar that cannot be ignored. They are articles, parts of speech, sentence pattern, tense, etc. Part of the grammar that is considered to be most difficult to learn for Indonesian students is tenses. Simple present tense is the example. Frank (1972:66) states that "simple present tense is used to express a habitual action with adverbs like usually, always, or often." The use of simple present tense often makes students confused with its complexity, especially for the $6^{\text {th }}$ semester of English Students in class D of IAIN Palopo. They usually have some problems in finding out the verb form of simple present tense. They often write "He walk to school everyday." instead of "He walks to school everyday." The third singular persons such as he, she, and it need suffix $-s$ or $-e s$ for the verb. It shows that Indonesian students do not consider that in English there are verbs formed in singular or plural. In Indonesian language, singular or plural forms do not affect the verb form. 


\section{Method}

The research design of this research is descriptive. It is conducted by collecting data in natural classroom situation without altering the situation in any way. In this case, this study intends to reveal what errors appear most in the learners' descriptive writing. Secondly, qualitative research studies real-world behavior as it occurs in the natural setting as they are found.

The research was conducted in $6^{\text {th }}$ semester of English Students Class D of IAIN Palopo. The data is collected by giving task to the students about descriptive text. They are asked to describe their favorite artist. $n$ this phase, the researcher studied the data obtained which were in the form of students' writing products. This data analysis was done in several steps. Those steps are identification of errors, classification of errors, statements of frequency of errors and description of errors in terms of their types. The first step in the process of the analysis was the identification of errors. Identifications of errors here refer to identification of any deviation in using grammatical structures found in students' writings. After identifying the errors, the total number of errors made by the students was covered.

\section{Results}

There were 85 errors found from the 20 written products of the students. The errors found were analyzed using the surface strategy taxonomy proposed by Dulay et al. (1982). Thus, the errors were classified into errors of omission, errors of addition, errors of misformation, and errors of misordering. This research only focused on the analysis of errors in simple present tense, while the other errors, which were not included to simple present tense, were ignored. However, the whole data were not presented in this chapter and only described by some representative data. The data in this research were analyzed descriptively.

In the analysis, the findings were presented in the types of error, the sample of sentences which contain errors, the revised version of the sample sentences, and the frequency of the occurrence. Surface strategy taxonomy by Dulay et al. (1982) was used to analyze the errors of this research. Surface strategy taxonomy analyzed the change of the surface structures of the sentence. It analyzed the errors in which learners may omit, add, misform, or even misorder components of the sentence. Based on surface taxonomy strategy, errors were classified into omission error, addition error, misformation, and misordering. The result from the analysis showed that there were 85 errors in using the present tense in the 20 students' writing. There were $47,05 \%$ errors of omission; $4,70 \%$ errors of addition; $45,88 \%$ errors of misformation; and $2,35 \%$ errors of misordering. 
Masruddin:

Omission: Common Simple Present Tense Errors in Students' Writing of Descriptive Text

\section{Errors of Omission}

Errors of omission were identified by the absence of an item or morpheme that must appear in an well-formed utterance (Dulay et al., 1982). This error occurred when the learners omitted some required components from their sentences. The learners omitted components which was/were necessary for their sentences to be considered grammatically correct. The errors of omission found in this research were the omission of auxiliary verbs (be), omission of verb inflection (marker-s/-es), and other omission errors.

1. Omission of auxiliary verbs (to be)

Omission of auxiliary verbs was the kind of omission error that mostly made by the students. There was $62.5 \%$ omission of auxiliary verbs (to be) errors from all omission error. The following sentences are the example:
a. It also not tidy
b. Many clothes hanging
c. The shoes on the sofa

Those sentences are not grammatically correct because the missing of auxiliary verbs or be before adjectives. Since the simple present tense needs be as well, it is necessary to put the auxiliary verbs or be after subject and before adjective. The auxiliary verbs (to be: is, am, are) should be inserted to the sentences Thus, the revised sentences should be:
a. It is also not tidy
b. Many clothes are hanging
c. The shoes are on the sofa

2. Omission of verb inflection (marker-s/-es)

The students made omission of verb inflection (marker -s/-es) errors in the percentage of $25 \%$ from all omission errors. The following sentences are the example:
a. The owner of the room put his shoes
b. He/she maybe forget to turn off his/her laptop
c. The clothes are not arrange tidy

Those sentences above have errors because the missing of s/es. Simple present tense needs verb inflection of s/es for specific subject. The first and the second sentences, the verbs need to be added with $s$. In the third sentence, the sentence is still simple present tense, but it is in the passive form. So, ed should be inserted after the verb. Thus, the revised sentences should be:
a. The owner of the room puts his shoes
b. He/she maybe forgets to turn off his/her laptop
c. The clothes are not arranged tidily. 


\section{Other omission errors}

There were other omissions of errors found in the students writing. The percentage was $12.5 \%$. The other omission of errors was the omission of subject. The sentences which have error of missing subject are:

a. In that room, is 3 T-shirts

b. At the door, text "STOP", "Do not Enter", and "Do not Disturb"

c. On the table, the stack book but it isn't tidy

It cannot be called as sentences since those sentences do not have subject and (auxiliary) verb. Thus, the revised sentences should be:
a. In that room, there are 3 T-shirts
b. At the door, there are text "STOP", "Do not Enter", and "Do not Disturb"
c. On the table, there is the stack book but it isn't tidy

\section{Errors of Addition}

Errors of addition were the opposite of omissions. These kinds of errors were identified by the presence of an item which is unnecessary or mostly not appear in well-formed sentences. There were three types of this kind of error. They were double marking, regularization, and simple addition. There was only one type of addition errors that was found in this research, which was addition of double marking.

\section{Addition of Double Marking}

Double marking is errors in which the learners fail to delete certain required components and give more than one marking in constructing sentences. The examples of this kind of errors are:
a. The room is does not tidy
b. Everything in this room is does not in that place
c. The bed is also are not arrange tidy

The sentences above have the same problem. In sentence (a) and (b), the auxiliary verb does should be omitted since there should be copula or be is before adjective. Then, in sentence (c), there are double of copula or be (is and are), then one of those should be omitted. Thus, the revised sentences should be:
a. The room is not tidy
b. Everything in this room is not in that place
c. The bed is also not arrange tidy

\section{Errors of Misformation}

The errors of misformation were identified by the use of wrong morpheme or structure. There were three types of these errors, which were regularization, archy form, alternating form. The error of misformation found in this research was only misformation of archy-forms. 


\section{Misformation of Archi-Forms}

Misformation of archy-form is the selection of one member of a class of forms to represent others in the class. The examples of the sentences are:
a. There are also a doll in the chair
b. The books is messy
c. I didn't like this room because the room is dirty

Those sentences above are incorrect due to the misformation of archiforms (be and auxiliary verbs). The copula or to be in the first and second sentence should be adjusted with the subject, whether it singular or plural subject and object. In the third sentence, the auxiliary verb (didn't) should in simple present tense form as it showed the present state or condition. Hence, the revised sentence should be:
a. There is also a doll in the chair
b. The books are messy
c. I don't like this room because the room is dirty

\section{Errors of Misordering}

Errors of misordering were characterized by the incorrect placement of a morpheme or group of morphemes in an utterance. This error has the percentage of $2.35 \%$ from all types of errors. The example of these errors are:

a. There are many thing not in that place

b. In the room are many thing not in that place

The revised sentences should be like:

a. Many thing are not in that place

b. In the room, many thing are not in that place

From the data, the errors with the highest frequency of occurrence were on errors of omission that made up $47,05 \%$ of all errors. The errors with the second highest frequency are misformation errors that appear as $45,88 \%$. The next is addition with $4,70 \%$ followed by misordering which makes up very little compared to the others with only $2,35 \%$.

\section{Discussion}

Omission is kind of error in which the learners omit or delete the components from the sentences (Dulay et al., 1982). In fact, those omitted components are necessary for their sentences. Dulay et al. (1982) states that errors of omission are found in greater abundance and across a greater variety of morphemes during the early stages of second language acquisition. While, in intermediate stages, when learners have been exposed to more of the language other types of errors are more likely to occur. 
From the result, it is found that omission errors come as the type of errors with the highest frequency of occurrence. Omission errors make up about $47,05 \%$ of all errors found in students' descriptive writing. These omission errors are dominated by omission of auxiliary verb (be). The highest omission error is in the omission of auxiliary verbs (be). It has percentage of $62,5 \%$ of all omission errors. This omission can be seen in the sentence "The shoes on the sofa" which is not correct and should be like "The shoes are on the sofa". In Bahasa Indonesia, there is no copula before preposition, for example "Sepasang sepatu di atas kursi". That sentence has subject of "Sepasang sepatu", preposition of "di", and "atas kursi" as adverb of place, yet no be existed. The next type of omission errors is the omission of verb inflection (marker-s/-es). It can be seen in the sentence "The owner of the room put his shoes". Since it should be in simple present tense form, the verbs should be added with $-s$-es marker for particular subject. The correct sentence should be "The owner of the room puts his shoes".

Since Bahasa Indonesia does not have any form of tenses, there is no different form of verbs for all subjects and for all form of tenses. For example, if there is sentence "Dani meletakkan sepatu di atas meja" in Bahasa, there is no change for verb "meletakkan" in any form of tenses. The last type of omission errors that found in this research is other omission error which is the omission of subject. This type of omission error comes up about $12,5 \%$ of all omission errors. It can be seen from the sentence "On the table, the stack book but it isn't tidy". That sentence is incorrect because it has no subject. In order to make meaningful sentence, the sentence should be grammatically correct. There should be subject, predicate (verb), object, and or adverbs in a sentence that are constructed grammatically correct.

Errors of omission come with the abundance number of occurrence frequency. This condition can be because of ignorance of the target language structure rules. The students might already know and intend to express certain idea and meaning, but because of their ignorance of or neglecting the target language structure rules, they may omit certain item that must appear in a wellformed sentence. Even though any morpheme or word in a sentence is a potential candidate to be omitted, language learners omit grammatical morphemes much more frequently (Dulay et al., 1982). Junior high school students are still in their early staged of second language acquisition especially in writing. While their lessons in elementary school primarily focus on introducing simple English.

Secondly, addition errors are the opposite of omissions. This kind of error is characterized by the presence of an item which is unnecessary in well-formed sentences. There are three kinds of errors in this class; double marking, regularization, and simple addition. 
Masruddin:

Omission: Common Simple Present Tense Errors in Students' Writing of Descriptive Text

Based on the result, it is found only one type of addition error in the form double marking. Double marking error occurs when the learners give more than one marking in constructing the utterance or sentence. This addition error can be seen in the sentence "The room is does not tidy". The sentence is grammatically wrong because it has double auxiliary verbs (is and does). The sentence should use only one auxiliary verb. Since the sentence explains the state, the adjective should be preceded by to be. Besides, the subject is a singular noun, so to be "is" should be used. It may happen because the students are still confused in using the appropriate verbs or auxiliary verbs related to the subject and the object (adjective).

The third type of error is misformation which is in the second position of highest occurrence frequency ( $45,88 \%$ of all type of errors). This kind of error is indicated by the use of wrong form or morpheme or structure. There are three typess of misformation errors. They are regularization, archi-form, and alternating error. Misformation of archi-form appears as the only type of errors found in misformation error. Archi-form is the selection of one member of a class of forms to represent others in the class is a common characteristic of all stages of second language acquisition. The example of this misformation error is "There are also a doll in the chair". This sentence is incorrect in terms of the use of to the copula be and the object.

This error might happen because the students did not realize that the sentence has singular object. Yet, the students may only recognize the subject "there" and may consider that "there" is followed by "are". That is why, are should be use instead of is. The other possible reason is that the students might still be confused in distinguishing the usage of is and are. This might be because there are many verb forms in English which are not found in Indonesian structure. Such cases like the concept of tenses, which determine the verb form, might be one of the reasons for this difficulty.

The last type of error is errors of misordering. It is characterized by the incorrect placement of a morpheme or a group of morphemes in an utterance. There are only two sentences found in the research which contain the archi-form type of misformation error. The example is "In the room are many thing not in that place". The position of the to be "are" is incorrect. It is should be placed after subject. The misordering errors seem to result from the interlanguage. Selinker (1972) states that interlanguage is the type of language produced by second and foreign language learners who are in the process of learning a language. This kind of errors indicates the interference of the students native language in their writing. According to Brown (2000), errors arise from several possible general sources. The two sources of error are "interlingual and intralingual transfer". They seem to explain the errors students made in his study. Interlingual transfer refers to the second language acquisition that reflects native language structure. Hence, 
according Brown's statement, the teacher cannot neglect that somehow the native language of the students affect them in acquiring the second or foreign language. Richards (1974) defines intralingual errors as those "which reflect the general characteristics of rule learning, such as faulty overgeneralization, incomplete application of rules, and failure to learn condition under which rules apply". Errors may therefore occur as a result of such intralingual interference, which involves an application of general learning strategies similar to those manifested in the first language acquisition (Richards, 1971).

The findings of this study seem to support the findings of the previous studies, in a way that the omission errors occur most frequently while misordering errors come last. The errors made by the students at acceleration class appear to be similar to those of regular program investigated in some of the previous studies. The findings indicate the errors where students have difficulties. They also indicate the students' mastery and stage in the process of learning the target language.

\section{Conclusion}

Based on the discussion of the findings presents in the previous chapter, the errors found seem to result from interlingual and intralingual interference. Therefore, the teachers are suggested to develop better method in teaching writing in order to reduce the number of errors and fossilization that done by the students. Besides, they should integrate the grammar in other skill teaching and learning process. They are suggested to pay more attention to the particular structures that often create difficulties for the students by selecting contextual exercise on the structures, which are often omitted, added, misformed, and misordered. In addition, the teachers should give clearer explanation about structure differences between Indonesian and English.

\section{References}

Bogdan, R. \& Beiklen, S.K. (1992). Qualitative Research for Education: An Introduction to Theory and Method (2nd ed). Massachusetts: Allyn and Bacon.

Corder, S.P. (1967). The Significance of Learners' Errors. Errors Analysis. Ed Jack Richards. London: Longman Group Ltd.

Ni'mah, L.F. (2016) An Analysis Of The Students' Ability In Writing A Descriptive Text On The Eighth Grade At MTSN Bandung In The Academic Year Of 2015/2016. https://teachingenglish4all.wordpress.com/2010/06/28/descriptive-text/ 